\title{
HUMAN DIGNITY IN AFRICA: SKETCHING THE HISTORICAL CONTEXT
}

\author{
Piet J Naudé \\ Unit for Ethics
}

Nelson Mandela Metropolitan University

\begin{abstract}
This article points out the notion of 'Africa' is notoriously complex and should be used with circumspection. It then proceeds to sketch the major historical forces that shaped large parts of the African continent as we know it today: The Atlantic slave trade; colonialism, post-colonial mis-rule, and the creation of a global economic system. These histories should be kept in mind when one reflects theologically about human dignity in relation to Africa.
\end{abstract}

Key Words: Africa, Human Dignity, Historical Context, Theological Reflection

\section{What/Who is 'Africa'?}

If one wishes to bring historical and contemporary perspectives into the debate on human dignity related to this continent, one is struck by the complexities of what is called 'Africa'. There is no one history for Africa, only a multitude of regional histories. 'Sub-Saharan Africa' is mostly used as geographical demarcation ${ }^{1}$ of the continent, but even in this region slavery, colonialism, post-colonial politics, and current socio-economic developments are widely divergent. In most cases this defies any unifying terms in which to speak about our continent. In South Africa itself, the question of who are real Africans, has been a perennial one in political and sociological debates, and the issue of identity clearly underlies claims like "Ik ben een Afrikaander" and "I am an African". For the purpose of an overview like this, we therefore have to accept generalizations beyond what would make serious historians, economists or political scientists feel comfortable. There are always exceptions to whatever is claimed in the name of 'Africa'.

This essay is not an attempt to speak 'on behalf of' Africa. This I cannot do as I neither have the requisite knowledge nor the mandate to do so. What is presented here, though, is a perspective on the context in which we can place our discussions on human dignity. This contextual view is developed via the work of the African Union, incorporated into my own views and a selection of auxiliary literature. This is followed by very preliminary theological observations about dignity and identity-formation.

The African Union (AU) was established as an inter-governmental organization in July 2001 as an amalgamation of the former African Economic Community and the Organization for African Union. Its headquarters are in Addis Ababa where the African Union Commission co-ordinates the work on behalf of the 53 member states. The AU has ambitious goals to achieve greater unity among African countries via the creation of a free trade area, a central African bank, a common currency and the creation of a single customs

The AU insists that one of Africa's greatest challenges is exactly to overcome divisions based on so many differences, for example, culture, language, religion, economic status and political systems (AUC 3:4-22). 
union. The AU aims "to promote and defend common African positions on issues of interest to the continent and its peoples" (www.african-union.org). The main sources for this paper are the Strategic Plan of the African Union Commission (3 volumes, 2004 quoted as AUC 1, 2 and 3) and the Economic Report on Africa 2007: Accelerating Africa's Development through Diversification (ERA) drafted by Economic Commission for Africa.

Africa is in serious need of socio-economic development, but is currently under threat of marginalization in an increasingly globalizing economy. Unlike Asia and Latin-America that succeeded in extracting great advantages from the global economy, Africa has failed to become an important member of the international economic community. The results are cause for deep concern and the source for a general Afro-pessimism inside and outside of Africa itself. Here is some basic information: ${ }^{2}$

- Africa's population of 832 million represents $13 \%$ of the world population, but Africa accounts for only $1 \%$ of FDI, $1 \%$ of gross domestic product and about $2 \%$ of world trade $\mathrm{e}^{3}$;

- Of the 48 least developed countries in the world, 35 are in Africa and African countries are mainly in the lowest $20 \%$ of the UN Human Development Index;

- Over $40 \%$ of the sub-Saharan population live below the international threshold of $\$ 1$ a day;

- Nearly $80 \%$ of the continent's labour force "remains mired in manual and archaic agricultural practices" (AUC 1:6) compounded by hostile climatic conditions and persistent animal diseases that threatens food security. Per capita food production fell in 31 of the 53 African countries in the period 2000-2005;

- Diseases like malaria and Aids (a deadly combination in many cases) are taking its daily toll on life-expectancies (2 million Aids deaths in 2005) and the economy: $60 \%$ of HIV-positive people world-wide live in Africa and on average adult HIV prevalence is $6.1 \%$ of the population (UNAIDS, 2006);

- Africa's isolation, marginalization and even exclusion (see Hoogvelt, 2002) is increasing due to the continued widening of the digital divide (AUC 1:13) with huge backlogs regarding intra-African communication and 'log-in' into the digital global economy.

This list can be extended, but is adequate to highlight the dire socio-economic development needs of Africa and the danger of remaining a marginalized continent. From an African perspective, a fair global trade regime must contribute to the continent's development and enhance Africa's ability to participate in the processes of global decision-making, overcoming its marginalized position and weak negotiating power, and ensuring that benefits accruing from global economic interaction are sustainable.

\section{Historical Background to the Debate about Human Dignity}

A large body of current paleo-anthropological research concurs that Africa - and specifically Southern Africa - is the cradle of both hominid evolution and the origin of Homo sapiens' migration to other parts of the world. The evidence emerging from the famous

This information is mostly available in AUC 1:9ff.

If one accepts that a very high percentage of international trade is "virtual" (shares, futures), Africa's share of real commodity trading - minerals, and increasingly oil - would be considerably higher. The lack of participation in all forms of trade is a sign of Africa's marginalization as it points to weak financial institutions and a lack of connectivity in a widening digital divide. 
Sterkfontein world heritage site north of Pretoria, as well as the recent findings in sea-caves in the Southern Cape, suggest that Africa is probably our common homeland, the geographical matrix of the human species. ${ }^{4}$

This stands in stark contrast to the history of successive 'inhumanities' in and increasing marginalization of Africa over the last few centuries. I take as an assumption that human dignity is fundamentally tied up with positive social identity construction. Such identity formation is a dynamic and ongoing historical, cultural, and economic process. 'Exploitation' and 'marginalization' are core factors that deny or at least seriously impede the construction of positive social identities.

As an African I argue that our current marginal position must be viewed from an historical perspective. Africa was a major force in world affairs at the time of its various empires and kingdoms for millennia BCE up to the $15^{\text {th }}$ century (AUC 1:4-5). The marginalization and exploitation of Africa and Africans, between the $15^{\text {th }}$ century and the present time, are the background to an understanding of the asymmetrical power situation and colonised mind-set that lies at the root of human indignity on this continent. There is mounting empirical evidence to support the argument for an implicit link (not direct 'causality') between history and the current economic performance of Africa. ${ }^{5}$ The point is that current 'indignities' arose over many centuries and is the cumulative result of at least three factors:

- The Atlantic slave trade (1440-1870);

- The colonization of Africa (1884-1961) and post-colonial mis-rule in Africa (1950 to present day);

- The creation of a global monetary system (1878-1990).

On each of these topics, hundreds of books have been written. For the purpose of this paper, I merely draw a very broad picture to inform our discussions at this colloquium.

\section{The Slave Trade 6}

The Atlantic slave trade developed over a period of just over 400 years (1440-1870). There is no scholarly consensus as to the origin, extent and effects of the slave trade on Africa and slave importing nations. A middle position would probably agree on the following:

Slave trading was an integral part of African societies, long before the actual Atlantic trade started. In the absence of clear rights to property, slaves (cheap labour) were an important means of production and slaves were taken from African tribes themselves, in the normal course of inter-tribal conflicts. ${ }^{7}$ However, it must be stated, that the rising demand for slave labour in the Americas led to an enormous expansion of intra-African trade in human capital, with competitive co-operation amongst European slave merchants and the African elite. Only in rare cases were slave raids undertaken by Europeans, through the course of war on the African continent. ${ }^{8}$ However, this does not

For a detailed discussion of the "Out of Africa" hypotheses and other views, see Van Huyssteen (2006:60-67). For an empirical argument, see Nathan Nunn (2007) and his many references to literature from development economists defending the link between Africa's current underdevelopment and historical legacies.

6 For this section I rely on Hugh Thomas's: The slave trade. The history of the Atlantic slave trade 1440-1870 (1997) and John Thornton's: Africa and Africans in the making of the Atlantic world, 1400-1800 ( $2^{\text {nd }}$ edition, 1998).

See Thornton's persuasive argument of the link between slavery and African social structure (1998:72-97).

8 See Thornton's discussion of early slave raids in Angola by the Portuguese army (1998:115), but also his sober conclusions regarding the link between European war-abilities and enslavement (1998:116ff). 
imply a passive role by Europeans, who entered into agreements with their African counterparts to ravage the lives and social structures of ordinary Africans.

The outcomes for Africa were mixed: On the one hand the barter trade in goods like iron, textiles and liquor, and the opportunity to access more advanced arms brought about many positive economic effects, including a diversification of the local economies. On the other hand, there were devastating demographic ${ }^{9}$ and social effects on African societies that were built primarily on kinship and patriarchy. The increasing power of African rulers, as a result of the slave trade, led to them selling even more people into slavery, thus perpetuating the social crisis.

The effect on the Americas and Europe were more uniformly positive: Africa provided a market for produced goods and was a source for labour that made possible the agricultural revolution in what is now known as Latin-America and parts of North America (then under European colonial rule). Contrary to Eric Williams's argument, ${ }^{10}$ no linear causal relationship between the slave trade and the subsequent emergence of industrialization is feasible. However, there is no doubt that industries like ship-building, marine insurance and ropemaking were stimulated by the slave trade and that the capital gained from trading humans and agricultural production by slaves (virtually free labour!) made a variety of industrial projects possible (Thomas, 1997:795).

Although the thesis by Walter Rodney that the Atlantic slave trade was a first step in the under-development of Africa, is no longer supported by main-stream academics, one has to state clearly: Between 10 and 13 million slaves exported from Africa ${ }^{11}$ played an indispensable role in the economic and cultural ${ }^{12}$ development of Europe and the Americas, and the rapid agricultural progress in these regions would have been very difficult - if not impossible - without enslaved African human capital.

\section{Colonialism ${ }^{13}$ and Post-colonial Africa}

The abolition of the slave trade eventually led to a markedly different economic and political relationship between Africa and Europe. What slowly emerged into focus was that Europe no longer needed to control human capital, but rather it needed economic and political control over actual African territories. This was in order to secure trade in goods like gold, ivory, timber and palm oil, and also to play out the competitive intra-European rivalries over the period 1870-1945.

9 The AUC refers to this as a "demographic haemorrhage occasioned by the paroxysm of the slave trade" (AUC 1:5).

10 Williams was the prime minister of Trinidad and wrote the controversial book Capitalism and slavery in which he argues for a link between slavery and industrialization.

11 See the estimated statistics of the slave trade as cited by Thomas (1997:805-806) in terms of carrier countries (Portugal 4.6 million and Britain 2.6 million); destinations (Brazil 4 million); origins (Congo/Angola 3 million) and type of labour (sugar plantations 5 million).

12 See Thornton's very interesting chapters (5-9) on the effect of slaves on the cultures of the so-called New World and how reciprocal transformations occurred.

13 For this section I rely heavily on JD Fage (1988). A history of Africa ( $2^{\text {nd }}$ edition). He commences his study with early African societies (part 1), the impact of Islam (part 2) and - for this paper more importantly - he discusses European expansion and colonial power in parts 3 and 4. The well-known book by Thomas Pakenham (1991) The scramble for Africa reads like a novel and focuses more closely on the colonial period and actual territorial invasion of Africa between 1870 and 1906. Each region is discussed in detail, and makes clear how complex the process of colonization was. A more journalistic book with a fairly critical view of Africa is Robert Guest's (2004) The Shackled Continent. He starts off by arguing that Africa's basic problem is not its past, but its lack of leadership in the post-colonial period (see pp. 12, 23). 
Trade in pre-colonial times was essentially co-determined by Africans and their European counterparts, where Africans (although mostly rulers and the trading elite) had a direct influence on events. However, we now enter a phase where asymmetrical power relations play themselves out on the African continent. Commenting on the nineteenth century, Fage observed: "In any clash between European and African interests or beliefs, Europe now possessed both the material means - steam power, firepower, medical power - to impose its will upon Africa, and the moral strength - the certainty that European civilization would prevail, and also that it was in the interest of the African peoples to do so" (Fage, 1988:333, see also p. 352).

Starting in West Africa and spreading over into South, East and North Africa, the major European countries increased their administrative, economic and eventually military-political control over Africa. By 1914, Africa - with rare exceptions like Liberia - were under foreign control ${ }^{14}$ (see map, Fage, 1998:402), and lost the ability to compete equally in the commercial exploitation of its own natural resources.

Both the process toward and the 'reasons' for colonization are too complex when examined over various regions, to summarize in one sentence. ${ }^{15}$ Colonization occurred in phases and whereas the initial phases of partial control were motivated by factors as diverse as securing the abolishment of the slave trade and expanding commercial trade in products such as palm oil, the later phases were more directly linked to European political events (the two World Wars and the depression of the 1930s). As Europe's industrialization reached its fulfilment, greater emphasis was placed on the direct economic benefits that the colonies could provide in the form of raw material (rubber, iron ore) and precious goods like oil, gold and diamonds.

Not all the colonies brought immediate profit and wealth to the colonizers and the idea that colonies are to be invested in only emerged much later in the colonization process. The first comprehensive development plans for the socio-economic upliftment of Africa occurred only after the Second World War (Fage, 1988:422-423). But the colonies were considered to be indispensable political building blocks in the intra-European conflicts among countries like Britain, France, Belgium, Italy, Germany and Spain (see Pakenham, 1991:xxii). The proverbial 'scramble for Africa' ${ }^{16}$ was driven by a powerful combination of economic and political forces, and was based on the emerging assumption that European civilization was superior to Africa's and that the latter needed developing towards a societal model based upon European religion and values. ${ }^{17}$

The rapid de-colonization of Africa started in the late 1940s and occurred inter alia due to the rising tide of nationalist liberation movements, political instability, and the acceptance of the Universal Declaration of Human Rights by the newly established United Nations. Post-colonial Africa was ill-prepared by its colonial and cultural histories to accept

14 Fage remarked that: "Europe and the world had accepted by 1902 that the whole of Africa was the property of one or other of the European colonial powers" (1988:391).

15 See Pakenham's fairly detailed accounts of the various regions, starting with King Leopold II of Belgium's dealings with the Congo.

16 The scramble for Africa is - as indicated above - the title of the magnificent account of colonization by Thomas Pakenham (1991), but the term itself has its origins probably as early as 1884 .

17 The link between Christian mission and colonial power is an ambiguous one. Pakenham states unequivocally that the scramble for Africa was led by "the empire-building alliance of God and Mammon" (1991:673), introduced as "Christianity, commerce and civilization" by British explorer, David Livingstone. For us in Africa, a fourth "c" is added: conquest. 
responsibilities for its own affairs. A number of factors contributed to a somewhat sombre picture of Africa after independence:

Colonial powers neglected to invest in general education, and training in politicaladministrative rule; power transitions were poorly managed; new rulers compiled economic policies that could not be sustained and which lead to indebtedness; dictatorships emerged due to weak civil societal structures, corruption and misrule became widespread; tribal wars escalated; and multi-party democracies were not sustainable due to inadequate levels of preparation for governments of this nature.

There is just no way in which we as Africans can escape the failures of leadership in many parts of post-colonial Africa and which have contributed to a general Afro-pessimism. The AUC mentions slavery and imperialism only in passing. It notes that we should not forget, but "we must learn to put things behind us" and focus on Africa's own responsibilities (AUC 1:7). The self-judgment is fierce and candid: "Distrust for constituted authority, corruption and impunity coupled with human rights abuses have kept Africa in a situation of conflict, thereby undermining all initiatives towards sustainable development" (AUC $1: 14)$. Coupled to this, is the deep and enduring socio-psychological impact of a colonized self-perception and a mind-set that leads to cultural diffidence and a notion that 'foreign' must be 'better'.

Although Africa eventually regained her political independence, an important factor crucial to the overall argument of this paper - must be kept in mind: Between 1935 and 1950 there were dramatic increases in foreign trade in areas like the Belgian Congo, French West Africa, Uganda and Northern Rhodesia (see table 5 in Fage, 1988:423), and by the mid 1950's "African colonies were participating in the world economy as never before" (Fage, 1988:423).

The question then arises: How was this world economy in which Africa was participating, structured? The answer to this important question lies in the emerging monetary system from the period of 1870 to the present day.

\section{The Evolution of the Contemporary Monetary and Trade Regime}

The growing economic integration of the world ${ }^{18}$ implies that decisions taken by one actor in the economic sphere affect other actors much more directly and intensely than ever before in history. It necessitates forms of co-operation to ensure orderly trade, generally accepted rules and regulations regarding stabilizing the various monetary systems inter alia through 'standardizing' exchange rates.

Economic historians ${ }^{19}$ generally agree that three such attempts at 'standardized monetarization' (SM) developed between 1870 and our present time: The Gold Standard, the Bretton Woods system and the current emerging system of free capital flow that is subject to negotiated trade rules.

The Gold Standard (GS), formalized in 1878, remained in force until the advent of the First World War. ${ }^{20}$ In simple terms, the monetarization at work here was to link the value of major currencies to a fixed price of gold, setting up a system of regulated exchange rates.

18 Madison (2001) shows how this integration has grown by indicating that for the world as a whole, the ratio of merchandise exports to GDP rose from $5.5 \%$ in 1950 to $17.2 \%$ in 1995 .

19 I am not an expert in economics or monetary policy and for this section rely heavily on the exposition by Peter Isard (2005), who was for many years a senior adviser at the IMF, and writer of Exchange rate economics (CUP, 1995).

20 There was fractional support for the GS up until 1933 - see Isard (2005:15, footnote 5). 
The initial key-currency areas committed themselves to a free flow of gold and to convert national currencies at a fixed rate into gold, when requested to do so. ${ }^{21}$ This created a system of standardized monetarization, facilitating international transactions and protecting participants against currency volatility. ${ }^{22}$

However, the collapse of the GS did not remove the need for international monetary cooperation. Already, during the Second World War, negotiations commenced that eventually led to a monetary agreement amongst forty-four nations at a conference in Bretton Woods, New Hampshire, July 1944. This became known as the Bretton Woods System (BWS) and entailed the declaration of fixed exchange rate parities by a substantial group of countries (Held, 1999:199-201).

In contrast to the GS, the BWS is a managed multilateral system that leaves individual countries with considerable autonomy to pursue national economic goals, whilst they subject their exchange rate and international trade practices to international agreements. Two important institutions embodied the BWS: The IMF focused on monetary cooperation and an orderly exchange rate system, whereas the World Bank financed economic reconstruction and development (Isard, 2005:27-29, 69-118).

Gold still played a role, although a considerably different international gold standard was established in this new exchange rate system. The US was the only country that actually pegged its currency to gold (at a par value of $35 \$$ per ounce), but other countries in turn pegged their currencies to the dollar. The BWS was thus a monetary system based on the dollar. In this system, private financial flows were restricted, and to diminish market volatility, the US undertook to sell gold only to foreign central banks and governments, and to licensed private users (Isard, 2005:29).

According to Held (1999:201-202), the BWS that formally operated between 1946 and 1971, broke down under exactly the three forces that shaped the current situation of financial globalization:

Firstly, the dramatic increase in highly mobile private capital put the control systems of the BWS under severe stress. Secondly, the emerging Eurocurrency markets (dollar deposits in European banks from multinational companies and the Soviet Union) were also not easily subjected to national capital controls. Thirdly, the OPEC crisis of 1973 resulted in huge flow of funds from oil-exporting to oil-importing countries. This increased the liquidity of international banks with an even greater flow of capital across national boundaries, and higher speculative trading.

In short, the intensity and increasing diversity of global financial flows broke the back of the BWS and its intended stable monetary system.

In the place of a fixed system where the value of gold, or the dollar acted as 'standardization measure', emerged a floating exchange rate system where the only remaining 'standard' is the value assigned to a particular currency by the day-to-day trading on foreign exchange markets (Held, 1999:209). Needless to say, in such a system volatility is higher and the power to determine market perceptions is a crucial factor in who will gain or loose. The 'hot money' of private speculators moves with great velocity and intensity. This has

21 For a simple explanation of the orthodox account of the Gold Standard, see Held et al. (1999:196).

22 In theory at least, this is the first example of a system embodying globally integrated financial markets, where domestic or national economies were subject to international financial discipline, to which they were required to adjust. One might refer to the Gold Standard as the origin of what has become known as economic globalization, i.e. "the increasing flow of goods and services, financial resources, workers, and technologies across national borders" (Isard, 2005:4). 
shown to have a significant impact on financial markets, in some cases leading to currency crises that threatened national and regional economies, due to the contagion effect of emerging market economies (Held, 1999:209, 213). ${ }^{23}$

This third, and still emerging evolution of the international monetary system, retained the major institutions of the BWS (the IMF and World Bank), although their roles were redefined as lessons were learnt about currency instability and development economics. To ensure some coherence in the increasing volume and extent of trade, the WTO replaced the failed GATT, and has become the only global international organization dealing with the rules of trade between nations, and acting as tribunal in case of disputes. General trade agreements reached at the WTO are ratified in the parliaments of participating nations, of which there were 146 in 2003 (Bhagwati, 2004:270).

In the first era, the gold standard was fairly tightly controlled with restricted national autonomy. In the BWS, there was more freedom to pursue national economic goals, but the stability was provided by the gold-dollar price and restrictions on private capital flow. In the current era, there is such a high degree of interconnectedness, and such a rapid flow of (speculative) capital that national autonomies are severely restricted - especially for weaker nations.

There has consequently been a structural shift in the balance of power between public and private authority in the global financial system. This is a matter of fierce debate and one may cite examples and counter-examples, but without being a 'hyperglobalist', one must admit that "there is much compelling evidence to suggest that contemporary financial globalisation is a market-driven rather than a state-driven phenomenon" (Held, 1999:234). The nation-state is, according to Stiglitz, squeezed between political demands at local level, and the economic demands of a global system. The problem is that economic globalisation has outpaced political globalisation, resulting in uncoordinated systems of global governance, particularly evident in issues of global health and the environment (Stiglitz, 2006:21). The power vacuum has been filled by the most powerful proponents of unlimited trade liberalization, and staunch believers in unfounded 'trickle-down' economics (Stiglitz, 2006:23).

For the purposes of this paper, I wish to point out a common element in all three monetary systems. From the beginning they created a fundamental differentiation between 'central' and 'periphery':

The gold standard was managed by the Bank of England in London; the BWS was dependent on dollar policies in Washington; the emerging financial system is determined by the triad of New York, London and Tokyo. Poorer countries today were for the most part still colonized when these monetary systems took shape and played only a marginal role in their origin and current direction. The consequence is that a hierarchical, uneven and asymmetrical system has emerged (Held, 1999:213, 224) with clear democratic deficits in decision-making power, and trade agreements that make the poorest countries worse off (Stiglitz, 2006:58).

This forms the background to the establishment of the WTO, the current trade negotiations, and the expectations that Africa has of the latter.

23 For a discussion of the different currency crises between 1994 and 1999 in Mexico, the Asian countries and Russia, read Isard (2005:119-151). 


\section{Conclusion: Human Dignity and the Quest for Identity Formation in Africa}

When one considers the broad historical context outlined above, the underlying question facing Africa is how to regain relative autonomy and initiative for a continent that lost its sense of self-worth over the last 500 years. This is extremely difficult for Africa, as she emerges from colonial and post-colonial (mis-)rule and finds itself on the margins of a global system from which she cannot and does not want to escape, but where the power to shape that system towards justice and equity is clearly lacking.

This fundamental question of identity underlies initiatives like NEPAD and the African Renaissance. Who are we? How can we proudly take our place in the league of nations? How can we overcome deep-seated Afro-pessimism?

In a courageous paragraph about the 'self', the AUC writes:

Therefore, as far as Africans are concerned, it is no longer a question of catching up with anything; it is no longer a question of trailing behind any one or being relegated to the sidelines by anyone; rather, it is a question of being at the centre of their own affairs. Africans should devise for themselves watchwords, namely self-development, selfreliance, self-reliance for recognition and development... Having thus clarified the direction of its endeavours for full development, Africa can seek to integrate itself into the globalization process without losing its soul (AUC 1:10).

One could translate the above as follows: Without reconstructing the African identity, socio-economic reconstruction will be extremely difficult. This brings questions about human dignity into the ethical arena of cultural justice (see Kwenda, 2003; Naude, 2005) and the rights of indigenous peoples. Only then follow the hard economic policies outlined by the AU: modernization of agriculture, acceleration of industrialization; beneficiation of Africa's enormous mineral wealth; integration of the sub-regions of Africa; and a decisive drive towards the diversification ${ }^{24}$ of African economies.

A multi-disciplinary exploration of "human dignity in Africa" will have to take these realities into account - so should a responsible, contextual Christian theology.

\section{BIBLIOGRAPHY}

African Union Commission 2004. Strategic Plan of the African Union Commission (3 volumes). Addis Ababa: AUC.

Bedford-Strohm, H 1993. Vorrang für die Armen. Auf dem Weg zu einer theologischen Theorie der Gerechtighkeit. Gütersloh: Chr. Kaiser Verlag.

Bhagwati, J 2004. In defense of globalization. Oxford: OUP.

Dunkley, G 2004. Free trade. Myth, reality and alternatives. Cape Town: David Philip.

Economic Commission for Africa 2007. Economic report on Africa 2007.

Addis Ababa: African Union.

Fage, JD 1988. A History of Africa. $2^{\text {nd }}$ edition. London: Unwin Hyman.

Guest, R 2004. The shackled continent. Africa's past, present and future. London: Macmillan.

24 Note the sub-title of the Economic Report on Africa: Accelerating Africa's development through diversification, and the discussion of diversification in the report itself (ERA, 2007:113ff). 
Held, D, McGrew, A, Goldblatt, D \& Perraton, J 1999. Global Transformations. Politics, economics and culture. Stanford: Stanford University Press.

Hoogvelt, A 2002. Globalization, Imperialism and exclusion: The case of Sub-Saharan Africa. In T Zack-Williams, D Frost, \& A Thomson (eds.), Africa in crisis. Challenges and possibilities (pp. 15-28). London: Pluto Press.

Isard, P 2005. Globalization and the international financial system. Cambridge: CUP.

Kwenda, CV 2003. Cultural justice: the pathway to reconciliation and social cohesion. In D Chidester, P Dexter, \& J Wilmot (eds.), What holds us together? Social cohesion in South Africa (pp. 67-80). Cape Town: HSRC Press.

Naudé, P 2005. The ethical challenge of identity formation and cultural justice in a globalizing world. Scriptura, 89, 536-549.

Nunn, N 2007. Historical legacies: A model linking Africa's past to its current underdevelopment. Journal of Development Economics, 83, 157-175.

Packenham, T 1991. The scramble for Africa.1876-1912. London: Abacus.

Stiglitz, JE 2002. Globalization and its discontents. London: Penguin.

Stiglitz, JE 2006. Making globalization work. New York: WW Norton.

Stiglitz, J \& Charlton, A 2005. Fair trade for all. How trade can promote development. Oxford: OUP.

Stiglitz, J \& Charlton, A 2006. Aid for trade. International Journal of Development Studies, $5(2), 1-41$.

Thomas, H 1997. The slave trade. The history of the Atlantic slave trade 1440-1870. London: Macmillan.

Thornton, J 1998. Africa and Africans in the making of the Atlantic world, 1400-1800 $2^{\text {nd }}$ edition. Cambridge: CUP.

UNAIDS 2006. Report on the global AIDS epidemic.

Van Huyssteen, W 2006. Unique in the world? Human uniqueness in science and theology. Grand Rapids: Eerdmans. 